\title{
INTERVIEW
}

\section{Assessing Critique, Scholarly 'Habits', Queer Method and 'Turns': An Interview with Heather Love}

\author{
Heather Love ${ }^{1 *}$, Salla Peltonen ${ }^{2}$
}

Published: October 30, 2017

\begin{abstract}
The interview considers the role of critique and epistemic habits within the fields of feminist, gender and queer studies. It addresses the collective, scholarly, activist and personal stakes in doing critical academic work as well as the politics of knowledge production. Assessing the role that the institutions have in producing critical knowledge it also discusses questions of method, description and 'turns' as well as material and social conditions of academic work.
\end{abstract}

Keywords: epistemic habits, critique, postcritique, queer method, description

\section{THE INTERVIEW}

Salla: How do you understand and assess the current discussions on critique and postcritique?

Heather: Because I've been working between the humanities and the social sciences I am interested in how a general questioning or rethinking of critique is happening across a bunch of fields simultaneously. There are critical ways to see that. You can see it as an effect of neoliberalism or as political despair, or as a reflection of the economic conditions of the contemporary university. I keep that explanation in mind, I suppose, as a critical, suspicious or paranoid account of what is going on. But it is possible to access other modes of thinking about our objects and even about power and domination without seeing them only within the frame of critique. People are trying to open up new modes of thinking. I want to keep a critical framework in mind but also resist the idea that post-critique is just cynical or professional or an epiphenomenon of neoliberalism.

Many areas of scholarly research can be revalued or transformed by branching out into different relations to critique. Bruno Latour is a really interesting example. He is one of the key architects of social construction in the sciences although he has distanced himself from that position now. I have in mind for example how in his Critical Inquiry piece "Why Has Critique Run Out of Steam?" he moves from a theory of the construction of facts in the sense of making them up to a more positive account of how the world is made, how it works. I think you can see those kinds of transitions in several domains. I don't have a great explanation for why this is happening, but it has opened a lot of new perspectives for me.

This moment reminds me of my own transition from a poststructuralist and psychoanalytic training to work on affect. I had learned to think about the subject in a very particular way, but was excited to discover other frameworks for thinking about psychic experience, embodiment, and feeling that were actually more descriptive and more capacious. I saw that as an opportunity because a lot of the material I was working with (on queer historical emotion) wasn't that amenable to a Freudian or Lacanian account.

Salla: What do you think these discussions are symptomatic of? Do you think it is a symptom of a craving for intellectual freedom on the one hand and wanting to think beyond the frames of our epistemic habits, or are the debates also a question of how we identify or position and identify ourselves as 'critics'? 
Heather: I tend to think of critics as constrained by their situation, their discursive community. I began by talking big about the global economy but we could also just talk about disciplines and academic departments. An example that I always return to is Bourdieu's account of skbole, or the scholastic orientation-the idea that you see the world from a library desk. I think the overvaluation of language, vis-a-vis other frameworks or domains of representation or experience, has to do with the fact that, as critics and writers, that we tend to value withdrawal rather than worldliness.

To address the significance of the university or even the profession as a framework for what we do is not only to write it off. I think we have a tendency to see scholars as more constrained than enabled by the dictates of academic scholarship. But I am not all that invested in the radical freedom that is blocked by the academy because, honestly, I am not sure would have ever written anything if it hadn't been for the profession. The structure and the sense of a broader conversation and history have all been very enabling for me. But I do think that a zone of freedom can open by bringing in something that doesn't really fit into that framework. I wrote a little piece for the Women's Review of Books a long time ago about Judith Butler, when Sarah Salih's edited reader came out. I cited that great moment from Undoing Gender in which she writes, 'the only way to describe me in my younger years was as a bar dyke who spent her days reading Hegel and her evenings, well, at the gay bar'. I see this attempt to reconcile discordant experiences and discourses as really generative-for Butler, for queer studies, and more generally.

I get excited when critics use personal experience in their work, because of the way it breaks the rules of academic discourse. I'm more interested in this as a discursive event than I am interested, necessarily, in the content of that experience (though sometimes I am pretty interested in that as well...). I have tried to use some autobiographical moments in my writing in order to mess with the conventions of academic writing — to create some intellectual and emotional space. It's not a practice of unfettered freedom but a kind of friction or tension that I find generative, I suppose.

I think that this interest partly explains my attraction to the bizarrely detailed micro-analytical accounts of everyday life that I have been working on most recently. These projects really don't fit in the frame of my training, and it's the wrenching of perspectives and the challenge that I find interesting. Even though these social science accounts are the opposite of more visceral or personal feminist or queer writing, they get me excited in similar ways because of the breaking of frames of standard modes of scholarship and writing.

Salla: What do you think of the state of academic critique formulated as different 'turns'? I am thinking about what critique does in these turns, what is at stake in formulating different turns as critical interventions? What do you think about this in relation to for example the descriptive turn?

Heather: I feel like you are asking me a structural or a formal question about how fields change. If it's about how the critique and post-critique debate played out in affect studies vs. queer studies, I could formulate a narrative specifically about that, somewhat partial and impressionistic — but it seems to be a more general question

The American Studies scholar Mark Seltzer has a critique of what he calls the turn turn. He asks why every academic article seems to be part of one turn or another, and he contextualises this fact in terms of the hyper reflexivity of second modernity (Ulrich Beck). It's a complex concept, related to the rise of cybernetics, the expansion of media, etc., which results in constant self-reflection and recording. So what's the point of thinking a thought if it can't also be registered as part of a larger process?

And why is it a turn? What is it about the idea of a turn? It has the progressivist associations of turning a new corner, turning over a new leaf, it's all about greet the new. But of course turning can also be about going nowhere fast. ${ }^{1}$ I don't think it can be separated from the commodification of knowledge and the fetishisation of novelty that is so fundamental to the discipline. How do you get ahead? It is by coining terms or shifting paradigms, or whatever.

Salla: Would you say those are epistemic habits of our fields?

Heather: I suppose I would frame epistemic habits in terms of the material underpinnings of university work. It has been interesting to work on the question of description at this moment. I am looking at all of these experiments, projects of complete description that were very time-consuming and that had very low stakes. So I am exploring the lowest thresholds of utility and interest and drama in scholarly work-and yet I find this stuff fascinating and beautiful. But in terms of my daily life, I spend so much of my time as an academic advisor,

\footnotetext{
${ }^{1}$ For this sense of turning (as well as another account of second modernity) see Justin Vivian Bond's mash-up of "Total Eclipse of the Heart" (“Turn around, bright eyes!”) with “Turn! Turn! Turn!", ("You Turn Me On, I'm a Radio)" and "Slouching Toward Bethlehem" ("Turning and turning in the widening gyre"). https://www.youtube.com/watch?v =oVpIZChta8
} 
encouraging $\mathrm{PhD}$ students to frame their scholarship in terms of bigger stakes, trying to help them get attention for their work in an economy of scarcity.

Salla: This is really an important question; I guess it is a question between the rhetoric of the critic and actually doing critical work.

\section{Heather: What do you mean critical work though?}

Salla: Feminist and queer studies have always been in the position of being against the institutions. In academic disciplines that understand themselves as doing a certain kind of critical work, critique gets routinised, and specific forms of critical thinking in a way become sedimented. Other frameworks of 'critique' might not be as easily recognised.

Heather: Yes, sure. But I don't agree with how earlier you characterised different forms of knowledge as mutually exclusive. There is no doubt to me that my deepest training in psychoanalysis and poststructuralism informs the work that I am doing now. This is a good aspect of the idea of a 'turn' because it implies continuity as well as transformation. I sometimes think about these changes is terms of drift. I feel like I drifted into affect studies-I mean it's not always intentional, it's hard to explain these motivations, sometimes you are just following instincts or looking for openings where you can find them. But I also worry about drifting too far out. There is a problem of generations and training: you try to learn what the person who trains you knows, but you can never read everything that they read. For example in the beginning of college I was reading a ton of Derrida without having read Husserl or Heidegger. This is one concern I have about the fetish of novelty, because you are so caught up in what is happening in a particular moment (and the late ' 80 s for deconstruction were really exciting) but then there is always so much to know and think about. If you are in the mode of perpetual critique, you can be really in the moment but actually have no idea what is going on. It's spicy, but you are like-where's the beef? This is what I try to balance in my role as teacher-because knowledge moves fast but also really slow, and it's hard to learn without recognising that.

I see my work on description and the social sciences in a dialectical relationship with deconstruction; it is very loving toward that body of thought. It's like, if you really pay attention to the work of those scholars then it should make you permanently tortured in regard to some fundamental questions (about representation and reality, about the primacy of language). Those are the questions I am asking now (but in a different idiom). I was deeply influenced by Barbara Johnson's work, for instance on persons and things, and by Eve Kosofsky Sedgwick's late engagements with Buddhism and Melanie Klein. It's been useful for me to think about their careers, about the dynamism of their thought over time.

In teaching, you pass on a particular method or mode, but what you really want to pass on is a historical sense or curiosity. Of course in a feminist context or in the context of 'subjugated knowledges' more broadly, the question of citation is essential. But cultivating and modeling a certain relation or orientation to the past is method.

Salla: My next question is about the energy of activist thought that is present in queer studies and often transforms into institutional forms of knowledge. The energy is often described as inspiration, but also as appropriation. Is there any another way of thinking about these kind of knowledge processes than through or as appropriation?

Heather: Because I've been in these kinds of feminist and queer communities my entire adult life, I've seen these fights played out so many times. I can be hurt by the polemics, but I am always interested. People often try to point out the complexity of the question - it's really not either/or, and lots of people are both academics and activists, or teachers and activists. I admire people who work effectively in both modes.

One of the places where this played out, and I wrote about this a little bit at the end of Feeling Backward, was at the controversial Gay Shame at the University of Michigan. There were many tough issues at the conference, but one of the things that interested me was a confrontation between members of the San Francisco anti-gentrification group Gay Shame and the academics in the audience. It was a tricky situation, with real concerns about appropriation (even of the name of the conference). Most of the invited speakers were known as academics, but they were also like, look, we're in this together, we are also doing activism. But I felt that the conflict that emerged was really about the material and economic conditions of activists and freelance artists versus professors, many of them tenured. When the topic is the politics of real estate, or the rights we have in our intellectual property, things get real very quickly. I felt that this conflict about queer radicalism and the academy v. activism was at its heart about economics and social class. I have a lot of ambivalence about the discussion of precarity by U.S. academics. Of course there are a lot of precarious people labouring in universities, but I am very aware of how tenure has 
made my life less precarious than the lives of almost anyone I know. I think acknowledgement of that lack of precarity is as important as acknowledgement of solidarity around shared precarity (which is more common).

Salla: How does your work on description relate to questions about accountability? I am thinking about the difference between engaging with works of art, novels and so and engaging with people.

Heather: I guess my modest proposal is for a lifetime of torment as people try to work out the relationship between theory and practice, or understand their job and its relationship to social change. I guess I am for mental torment, actually. I mean, I know that guilt has its limits as a political emotion-that it can be paralysing, selfserving, etc. But let's just think about the alternative: not being guilty. That's not so great either. I think the important thing is to take into account our position-I mean that in the sense of an intellectual and political orientation, and in terms of material and social relations. For me, becoming an academic felt like an incredible stroke of luck. But the longer I go on my thinking about accountability becomes and more complicated. I certainly don't think I have worked this out-but I did at a certain point become really uncomfortable with rhetorical solutions to material problems. I am talking about the uplifting endings of Left academic essays, that offer a sense of possibility in the face of injustice and horror. The idea is that it is important to be able to imagine change that is not yet possible in our world, and I understand that. It is so deeply tied to aesthetic experience, which is why I am here in the first place, so of course I understand that also. But at a certain point I burned out on it, started to mistrust my ability to provide that kind of consolation in language-because honestly, it costs me nothing. It's out of my sense of a political and really, for me, an emotional and ethical dead end that I've been interested in thinking through new modes of writing and thinking.

Salla: You have written about the messiness of everyday life. What happens with critique if we shift our attention from ideology and system critique and the kind of 'big claims' into messiness of everyday life? They are interrelated, of course, but what are the stakes for you or queer studies in focusing our attention more on the details, the particular cases, the everyday?

Heather: The normativity issue has incited a serious crisis in the field. One definition of queer studies is that it is activist because it is critical. Antihomophobic inquiry - it is not like other scholarly fields, it's not about knowledge production but rather oriented primarily to social transformation.

The entire field turns on that paradox, and how to be an academic discipline whose job it is to change the world. That contradiction structures all of our discourse no matter what position we take on these questions. Part of why I am interested in the queer ordinary or the messiness of everyday life is because I think contemplating the real complexity of actual situations is an important challenge to theory. If politics could proceed according to a blueprint then we would have fixed the world by now. The danger of leading with mess is that you will not get to politics, you will just be lost in the details-muddling through, but never getting anywhere. I think that is a legitimate fear, but nonetheless I've become very interested in this approach.

Salla: Would you say getting lost in the detail is a fear of getting depoliticised?

\section{Heather: Yes}

Salla: Not everything is about politics and thinking about ethics beyond the frameworks of accountability seems difficult. Your work, I think, is an example that we can do something else, that one can move beyond given frameworks and that there is an ethics to being a gender or queer studies scholar doing critique in reading a novel (or working with another kind of object) and having something to say about it.

Heather: I am not saying that I want to carve out a zone that is separate from politics so much as that I want to approach politics in a different way: via the minor, and the particular, and the everyday. But if I wanted to do work that was apolitical, that route is open to me through a more straight-up literary studies (my primary field of training). But despite some frustrations and disappointments and hurt feelings, I am still in the field of queer studies - the horizon of politics is still the ultimate horizon for me. But I want to be able to take the long way around — or I feel that the long way is the only way.

One way to make this more concrete is around the question of social class. I've been trying to argue recently that we need to engage more with descriptions of working class culture. Again, because of how I was trained (and my indebtedness to Marxist thinking), there is a tendency to think about class as a structure rather than an experience. And again, given the class make-up of the profession and the university, it feels like a productive wrenching of frames to even talk about non-elite ways of life in academia. Of course there is a precedent in cultural 
studies, African-American studies, and ethnic studies, but queer studies has a way to go on this front I think (not to mention English departments).

Salla: It's a point about the multiplicity of all kinds of political work: one of the huge epistemic habits is to say what one can and can't do with a certain framework, and then to question it.

Heather: The other thing I would like to mention in this context the habit of polemic. That's a habit that we are all trapped in, like every discussion turns into a pitched battle.

Salla: Queer studies often is characterised as not having a subject or an object. It only has X? Would you like to fill in the $\mathrm{X}$ ? Not as a definition, but giving it content, maybe as a description?

Heather: Well, I would probably just refer to Sedgwick's universalising/minoritising discussion—we all go back to it because it's fucking smart and true. But I am also attracted to other ways of thinking about this question through my work on the history of queer and deviance studies, and also the social science legacy of sexuality studies. I guess even though my own work is about representation and language, and pretty skeptical about identity, I think we make a big mistake by underestimating the value or complexity of empirical work. And in a moment of the queering of everything, I think grounded work on sexual communities and practices is very important. Being in conversation over the past several years with scholars like Gayle Rubin, Roderick Ferguson, and Cindy Patton has helped me to think about these histories, and also about the importance of cultivating respect for scholars (and people) with epistemic habits unlike our own. It's a basic point, but it bears repeating.

\section{REFERENCES}

Butler, J. (2004). Undoing Gender. London and New York: Routledge.

Latour, B. (2004). Why Has Critique Run out of Steam? From Matters of Fact to Matters of Concern. Critical Inquiry, 30(2), pp. 225-248.

Love, H. (2007). Feeling Backward: Loss and the Politics of Queer History. Cambridge, Massachusetts: Harvard University Press.

Salih, S. (ed.) (2004). The Judith Butler Reader. New York: Wiley-Blackwell.

\section{FURTHER READING}

Bourdieu, P. (1990). The Scholastic Point of View. Cultural Anthropology, 5(4), pp. 380-391.

Johnson, B. (2010). Persons and Things. Cambridge, MA: Harvard University Press.

Love, H. (2010). Close But Not Deep: Literary Ethics and the Descriptive Turn. New Literary History, (41)2, pp. 371-391.

Sedgwick, E.K. (1990). Epistemology of the Closet. Berkeley, CA: University of California Press.

Sedgwick, E.K. (2003). Touching Feeling: Affect, Pedagogy, Performativity. Durham, NC: Duke University Press.

Seltzer, M. (2016). The Official World. Durham, NC: Duke University Press.

Stryker, S. (2006). (De)Subjugated Knowledges: An Introduction to Transgender Studies. In: S. Stryker and S. Whittle, eds., The Transgender Studies Reader (pp. 1-17). New York: Routledge.

Citation: Love, H. and Peltonen, S. (2017). Assessing Critique, Scholarly 'Habits', Queer Method and 'Turns': An Interview with Heather Love. Feminist Encounters: A Journal of Critical Studies in Culture and Politics, 1(1), 10. https://doi.org/10.20897/femenc.201710

Copyright (C) 2017 by Author/s and Licensed by Lectito BV, Netherlands. This is an open access article distributed under the Creative Commons Attribution License which permits unrestricted use, distribution, and reproduction in any medium, provided the original work is properly cited. 